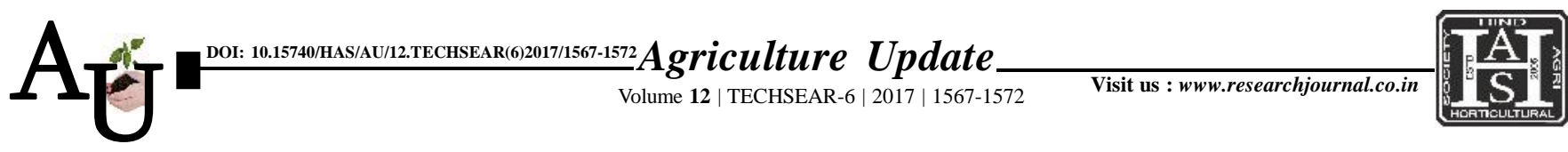

\title{
Research Article: Effect of different organic manures, inorganic fertilizers and growth regulator on yield attributes and yield of greengram (Vigna radiata L.)
}

\author{
口 PARVATI GADI, JOY DAWSON AND M. SHANKAR
}

Article Chronicle : Received : 17.07.2017;

Accepted : 01.08 .2017

KEY WoRds:

Greengram, Inorganic fertilizers, Farm yard manure,

Vermicompost, Polutry manure, Gibberillic acid, Yield
SUMMARY : The experiment was conducted during Kharif 2014-15 at Crop Research Farm, Department of Agronomy, SHAITS, Allahabad to study the effect of organic manures (farm yard manure, vermicompost and polutry manure), inorganic fertilizers (Nitrogen, Phosphorus and Potash) and growth regulator (Gibberellic acid) on yield attributes and yield in green gram, Vigna radiata (L.). The experiment was laid out in Randomized Block Design with thirteen treatments in three replications. Application of $10-40-20 \mathrm{NPK} \mathrm{kg} / \mathrm{ha}+10 \mathrm{~kg} / \mathrm{ha} \mathrm{N}$ through poultry manure+GA3 75+75 ppm was recorded significantly maximum number of pods per plant, number of grains per pod, test weight $(\mathrm{g})$, grain yield and straw yield in greengram as compared to the all other treatments .

How to cite this article : Gadi, Parvati, Dawson, Joy and Shankar, M. (2017). Effect of different organic manures, inorganic fertilizers and growth regulator on yield attributes and yield of greengram (Vigna radiata L.). Agric. Update, 12(TECHSEAR-6) : 1567-1572; DOI: 10.15740/HAS/AU/12. TECHSEAR(6)2017/1567-1572.

\section{Author for correspondence :}

\section{PARVATI GADI}

Department of Agronomy, Allahabad School of Agriculture, SHIATS, ALLAHABAD (U.P.) INDIA 